\title{
PENGARUH PERUBAHAN LUAS TUTUPAN LAHAN HUTAN TERHADAP KARAKTERISTIK HIDROLOGI DAS CITARUM HULU
}

\author{
Andi Gustiani Salim, I Wayan S. Dharmawan, dan Budi Hadi Narendra
}

Pusat Penelitian dan Pengembangan Hutan; e-mail: a_gustiani@yahoo.com

\begin{abstract}
ABSTRAK
Penurunan sumber daya air dan terjadinya berbagai bencana hidrologis di DAS Citarum menunjukkan perlunya penataan kembali komponen-komponen DAS yang ada di dalamnya, terutama tutupan lahan di wilayah hulu DAS. Penelitian ini bertujuan untuk mengetahui pengaruh perubahan luas tutupan lahan hutan terhadap parameter hidrologi DAS Citarum bagian hulu melalui simulasi model SWAT (Soil and Water Assessement Tool). Hasil penelitian menunjukkan bahwa luas tutupan hutan di DAS Citarum hanya sebesar 15,96\% dari luas DAS dan hanya terdapat 4,94\% di wilayah DAS Citarum Hulu. Nilai Koefisien Rejim Aliran (KRA) DAS Citarum hulu sebesar 31,4, rata-rata aliran permukaan tahunan dan erosi tahunan masing-masing sebesar 933,03 mm dan 517,9 ton/ha. Hasil simulasi beberapa skenario menunjukkan bahwa penurunan luas tutupan hutan dapat meningkatkan debit dan aliran permukaan, sebaliknya peningkatan luas tutupan hutan akan meningkatkan infiltrasi tanah dan evapotranspirasi. Penurunan luas tutupan hutan sebesar 10\% dari kondisi existing menyebabkan 58\% air hujan yang jatuh menjadi limpasan permukaan. Banyaknya ketidaksesuaian antara kondisi existing dengan arahan dalam RTRWP akan membutuhkan waktu lama dan biaya besar dalam penyesuaiannya, sehingga alternatif jangka pendek yang bisa dilakukan adalah mengkonversi tutupan pertanian lahan kering menjadi hutan untuk mencapai tutupan hutan minimal 45\% dari luasan lahan di wilayah hulu, dan dapat mengoptimalkan fungsi hidrologi DAS.
\end{abstract}

Kata kunci: Tutupan hutan, Hidrologi, debit, aliran permukaan, DAS Citarum Hulu

\begin{abstract}
The decline in water resources and the occurrence of various hydrological disasters in the Citarum watershed indicate the need to restructure the components inside the watershed, especially land cover in the upper watershed area. This study aims to determine the effect of changes in forest cover area on the hydrological parameters of the upstream Citarum watershed through simulations of the SWAT (Soil and Water Assessment Tool) model. The results showed that the forest cover in the Citarum watershed was only $15.96 \%$ of the watershed area and only 4.94\% was located in the Upper area. The Flow Rate Coefficient of the upstream Citarum watershed is 31.4, the annual average surface flow and annual erosion are $933.03 \mathrm{~mm}$ and 517.9 tons/ha respectively. The simulation from several scenarios shows that a decreasing in forest area can increase discharge and surface runoff, whereas an increase in forest area will increase soil infiltration and evapotranspiration. Decreasing forest area by $10 \%$ from existing conditions caused $58 \%$ of rainwater to become surface runoff. The large number of discrepancies between the existing conditions and the directions in the RTRWP will require a long time and large costs to adjust so that the short-term alternative that can be done is to convert dryland agricultural cover to the forest to reach forest cover of at least $45 \%$ of the land area in the upstream area and can optimize the hydrological function of the watershed.
\end{abstract}

Key words: Forest cover, hydrological, discharge, surface runoff, upper Citarum Watershed

Citation: Salim, A.G., Dharmawan I W. S., dan Narendra, B.H. (2019). Pengaruh Luas Tutupan Lahan Hutan Terhadap Karakteristik Hidrologi DAS Citarum Hulu. Jurnal Ilmu Lingkungan, 17(2),333-340, doi:10.14710/jil.17.2.333-340

\section{Pendahuluan}

Menurut Rencana Pembangunan Jangka Menengah Nasional (RPJMN) 2015-2019, Daerah Aliran Sungai (DAS) Citarum merupakan salah satu DAS prioritas yang harus dipulihkan kesehatannya bersama 5 DAS Prioritas lainnya karena kondisi lahan dan hidrologinya yang semakin menurun. Buruknya pengelolaan DAS Citarum menyebabkan tingginya tingkat erosi, aliran permukaan, banjir, tanah longsor, kekeringan, dan pencemaran yang terjadi di wilayah DAS. Salah satu penyebab utama terjadinya bencana alam yang terkait dengan air (water related disaster) adalah daya dukung DAS sebagai suatu kesatuan ekosistem masih sangat rendah (Kemenhut dan UGM, 2014).

Perubahan tutupan lahan terutama pada hutan di wilayah hulu DAS menimbulkan lahan-lahan terbuka, terdegradasi, dan kritis sehingga erosi, 
banjir dan kekeringan menjadi langganan wilayah hulu Citarum. Aliran permukaan di DAS Citarum hulu mencapai $3.632,50$ juta $\mathrm{m}^{3} /$ tahun dan kelas indeks erosi sangat buruk yaitu 491 ton/ha/tahun dengan jumlah erosi total adalah 112 juta ton/tahun (Imansyah, 2012; BPDAS Citarum Ciliwung - IPB, 2011). Selain itu, bahaya kekeringan menyebabkan wilayah Kabupaten Bandung, Kota Bandung, dan Kota Cimahi termasuk dalam wilayah berkategori kemiskinan air cukup tinggi atau dalam kondisi tidak aman (Maulani et al., 2013).

Konversi lahan hutan menjadi areal permukiman akan menghilangkan peranan daerah hulu sebagai wilayah resapan air dan perlindungan daerah di bawahnya. Berdasarkan hasil analisis peta tutupan lahan tahun 2015 (Kementerian LHK, 2015), menunjukkan bahwa luas hutan di DAS Citarum adalah $110.211,6$ ha $(15,96 \%)$ masing-masing terdistribusi di wilayah hulu, tengah dan hilir seluas $34.095,25$ ha $(4,94 \%), 57.178,70$ ha $(8,28 \%)$, dan $18.937,65$ ha $(2,74 \%)$. Pada tutupan wilayah hulu hanya terdapat $4,94 \%$ hutan, angka yang sangat kecil karena wilayah hulu DAS seharusnya merupakan daerah resapan air. Wilayah ini diharapkan memiliki luas tutupan hutan yang lebih besar jika dibandingkan dengan peruntukan lainnya. Terlebih jika berlandaskan pada amanat UU No. 41 tahun 1999 tentang kehutanan yang mensyaratkan luas hutan dalam suatu wilayah DAS adalah 30 persen dari luas DAS dan atau pulau dengan sebaran yang proporsional, maka kondisi wilayah hulu ini sangat memprihatinkan.

Hasil-hasil penelitian telah menunjukkan adanya hutan secara signifikan dapat mempengaruhi tata air DAS, meskipun luas tutupan (hutan) optimal pada masing-masing wilayah berbeda-beda tergantung biofisik DAS (wilayah) tersebut (Irsyad, 2011; Mulyana, 2012; Yusuf, 2010; Hanifiyani, 2015, Mubarok, et al., 2015, dan Yustika, 2013). Hasil penelitian BPTKP DAS Solo berdasarkan debit puncak dan sedimentasi hutan jati di Cepu, hutan pinus di Gombong, dan hutan lindung di Tawangmang menunjukan bahwa luas optimal wilayah hutannya masing-masing sebesar 45-47\%, 31-37\%, dan 64\% dari luas DAS. Di masa yang akan datang diharapkan bahwa pelaksanaan tata ruang wilayah mempertimbangkan luas hutan minimal dalam suatu DAS atau sebesar 30\% atau lebih (Badan Litbang dan Inovasi, 2016).

Penurunan sumber daya air DAS Citarum menunjukkan perlunya penataan kembali komponen-komponen DAS yang ada di dalamnya, terutama tutupan lahan di wilayah hulu DAS. Penelitian ini bertujuan untuk mengetahui pengaruh perubahan luas tutupan lahan hutan terhadap parameter hidrologi DAS Citarum bagian hulu melalui simulasi model SWAT (Soil and Water Assessement Tool). Hasil penelitian ini diharapkan dapat menjadi bahan masukan bagi para pihak dalam melakukan perencanaan pengelolaan DAS maupun dalam revisi rencana tata ruang wilayah.

\section{Metode Penelitian}

\subsection{Waktu dan Lokasi Penelitian}

Penelitian dilakukan pada tahun 2015 dan 2016 di DAS Citarum Hulu yang meliputi 6 (enam) Sub DAS yaitu Sub DAS Cikapundung, Cikeruh, Citarik, Cirasea, Cisangkuy, dan Ciwidey. Secara geografis terletak di antara $107^{\circ} 22^{\prime} 50.606^{\prime \prime} \mathrm{LT}$ - 107056'46.297"LT dan 6045'40.112"LS - 7014'27.018"LS seperti terlihat pada Gambar 1. DAS Citarum Hulu secara administratif pemerintahan berada di wilayah Kodya Bandung, Kabupaten Bandung, dan Kabupaten Sumedang, Provinsi Jawa Barat.

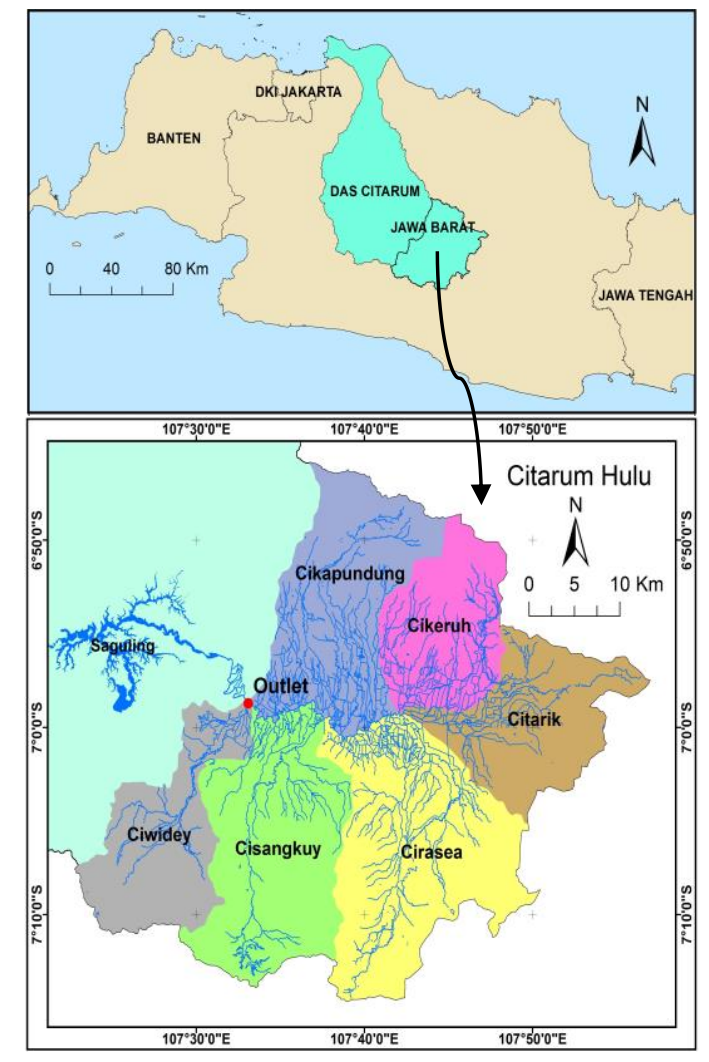

Gambar 1. Lokasi Penelitian

Sumber: Analisis peta batas DAS dan rupa bumi Indonesia tahun 2015

\subsection{Bahan dan Alat}

Bahan dan alat yang digunakan dalam penelitian ini meliputi GPS, seperangkat komputer yang dilengkapi perangkat lunak ArcGis 10, ArcSwat 2012, ring sampel tanah dan alat pengambil sampel tanah, meteran, perlengkapan lapangan lainnya dan alat tulis.

\subsection{Pengumpulan Data}

Data sekunder yang digunakan meliputi peta rupa bumi Indonesia digital $1: 25000$, peta DEM (Digital Elevation Model), peta jenis tanah (skala 1 : 100.000 dari Puslittanak Bogor) dan peta tutupan lahan tahun 2015 skala 1 : 100.000 hasil interpretasi citra landsat dari Ditjen Planologi Kementerian Lingkunga Hidup dan Kehutanan, data iklim (suhu maksimum dan minimum bulanan, kelembaban relatif, lama penyinaran matahari, kecepatan angin rata-rata 
bulanan) yang diperoleh dari Badan Meteorologi Klimatologi dan Geofisika dari stasiun terdekat, data curah hujan harian dan debit harian yang diperoleh dari Balai Besar Wilayah Sungai Citarum dan Dinas Pengelolaan Sumber Daya Air Provinsi Jawa Barat.

Data primer yang digunakan berupa karakteristik tanah yang diperoleh melalui pengamatan profil tanah di lapangan dan analisis sifat fisika dan kimia tanah di laboratorium terhadap sampel tanah yang diambil di lapangan. Variabel karakteristik tanah yang dianalisis adalah solum (mm), infiltrasi, tekstur tanah, bulk density, kapasitas menahan air, permeabilitas, nilai erodibilitas dan bahan organik.

Data karakteristik sungai (saluran) berdasarkan hasil pengamatan dan pengukuran di lapangan meliputi: lebar sungai, kedalaman sungai, tinggi muka air, konduktivitas hidrolik, permeabilitas, kekasaran manning dan penutupan saluran serta pengambilan sampel air untuk analisis kandungan TDS, TSS, COD, dan BOD. Ground check dilakukan untuk validasi peta topografi dan tutupan lahan.

Penelitian ini dilakukan dengan mengaplikasikan Model SWAT yang merupakan physically based model dan semi distributed model. Daur hidrologi dalam suatu DAS dapat disimulasikan melalui pemodelan SWAT (Neitsch et al., 2011).

\subsection{Penggunaan model SWAT}

Analisis model SWAT dilakukan untuk menduga dampak perubahan luas hutan terhadap respon hidrologi. Tahapan yang dilakukan terlihat pada Gambar 2 meliputi penyiapan data sesuai dengan format yang telah ditentukan ke dalam data input file, delineasi daerah penelitian (batas DAS), pembentukan HRU (Hydrological Response Unit), menjalankan SWAT, kalibrasi dan validasi model, dan simulasi model.

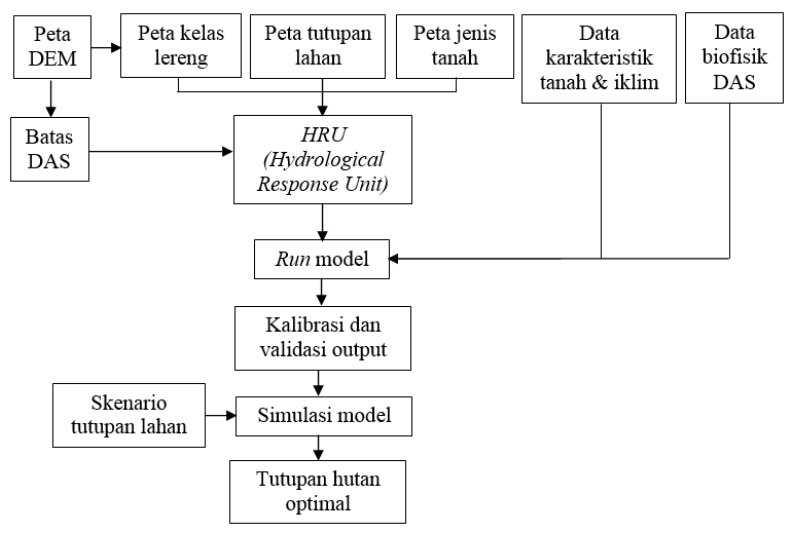

Gambar 2. Tahapan Analisis SWAT

Data spasial berupa peta DEM, tutupan lahan, dan jenis tanah dikoreksi sesuai dengan batas DAS yang dianalisis. Seluruh peta yang digunakan diubah menjadi sistem proyeksi UTM (Universal Transverse
Mercator). Data stasiun iklim dan pos hujan yang digunakan datanya dalam analisis SWAT disiapkan dalam format file text (.txt) berisi informasi kode stasiun, elevasi, dan koordinatnya. Data curah hujan harian disusun dalam format file teks berekstensi pcp, sedangkan data temperatur udara harian disusun dalam format file teks berekstensi tmp.

Pembuatan batas DAS secara otomatis menggunakan fasilitas automatic watershed delineation pada program ArcSWAT. Input dalam tahap ini berupa peta DEM pada proyeksi sistem UTM zona 48S-datum WGS84. Proses dilanjutkan dengan pembentukan unit respon hidrologi dengan input berupa peta tutupan lahan, jenis tanah, dan kelas kemiringan lereng. Tahap berikutnya adalah menjalankan (running) SWAT dan menyimpan hasilnya untuk dikalibrasi. Kalibrasi dan evaluasi didasarkan pada nilai $\mathrm{R}^{2}$ dan efisiensi model NSE (Nash Sutcliffe Efficiency), sedangkan validasi model dilakukan pada data debit yaitu dengan cara parameter yang sudah dikalibrasi dimasukkan pada data simulasi. Selanjutnya membandingkan data observasi dan hasil simulasi debit terkalibrasi. Metode statistik yang digunakan adalah korelasi koefisien Pearson (R) dan Nash-Sutcliffe coefficient of efficiency (NSE). Kriteria statistik NSE pada validasi sama dengan kalibrasi. Kriteria nilai statistik NSE menurut Moriasi et al. (2007) yaitu $0,75<\mathrm{NSE}<1,00$ (sangat baik); 0,65<NSE $<0,75$ (baik); $0,50<\mathrm{NSE}<0,65$ (memuaskan); dan NSE $\leq 0,50$ (kurang memuaskan).

Aplikasi model dilakukan dengan mensimulasikan beberapa skenario. Hutan, pertanian lahan kering, dan permukiman merupakan parameter tutupan lahan yang paling berpengaruh terhadap tata air DAS sehingga merupakan faktor penting dalam simulasi. Skenario disusun atas beberapa pertimbangan yaitu: Skenario 2015 (existing) merupakan kondisi berdasarkan tutupan lahan tahun 2015; skenario 1 dan 3 merupakan kecenderungan yang saat ini terjadi yaitu konversi hutan, baik sebagai permukiman (Skenario 1) maupun sebagai pertanian lahan kering (skenario 3). Skenario 2 merujuk pada RTRW Provinsi dengan mengkonversi pertanian lahan kering, semak belukar, dan tanah terbuka menjadi hutan hingga mencapai 45\%. Skenario 4 disusun berdasarkan RTRTW Provinsi Jawa Barat dimana kawasan hutan $>45 \%$ (Kawasan lindung mencapai 50,59\%). Adapun skenario yang disimulasikan ditunjukkan pada Tabel 1.

Tabel 1. Skenario yang Disimulasikan

\begin{tabular}{cccc}
\hline \hline & \multicolumn{3}{c}{ Luas (\%) } \\
\cline { 2 - 4 } Skenario & Hutan & $\begin{array}{c}\text { Pertanian } \\
\text { lahan } \\
\text { kering }\end{array}$ & Permukiman \\
\hline 2015 (Existing) & 20 & 25 & 20 \\
1 & 10 & 25 & 30 \\
2 & 45 & 15 & 20 \\
3 & 10 & 35 & 20 \\
4 & Sesuai dengan RTRW Provinsi Jawa Barat \\
& (Kawasan Lindung > 45\%) \\
\hline
\end{tabular}




\section{HASIL DAN PEMBAHASAN}

\subsection{Karakteristik DAS Citarum Hulu}

Wilayah DAS Citarum bagian hulu terdiri atas 6 (enam) Sub DAS dengan outlet di Nanjung sebelum akhirnya masuk ke Waduk Saguling. Luas DAS Citarum hulu hasil delineasi data DEM dengan model SWAT adalah 168.907,28 ha yang terdiri dari Sub DAS Ciwidey, Cisangkuy, Cirasea, Citarik, Cikeruh, dan Cikapundung. Daerah Aliran Sungai (DAS) Citarum bagian hulu berada pada ketinggian $600 \mathrm{~m}$ dpl - $2600 \mathrm{~m}$ dpl. Distribusi wilayah curah hujan di DAS Citarum bagian hulu tidak merata. Curah Hujan tahunan bervariasi antara $1.966-2.600 \mathrm{~mm}$. Bulan terbasah mencapai $300 \mathrm{~mm}$. Secara umum iklim DAS Citarum bagian hulu digolongkan sebagai iklim tipe $\mathrm{C}$ menurut klasifikasi Schmidth dan Fergusson atau tipe Am menurut klasifikasi Koppen (BPDAS Citarum-Ciliwung dan IPB, 2011).

DAS Citarum bagian hulu merupakan wilayah yang dikelilingi oleh deretan pegunungan dengan kelas kemiringan lereng yang cukup bervariasi, didominasi oleh kelerengan 41-60\% (sangat curam) seluas 73.632 ha $(43,59 \%)$. Kelas kemiringan lereng datar sampai landai (0-15\%) hanya seluas 36.795 ha (21.78\%), umumnya berupa lahan permukiman.

Jenis tanah di DAS Citarum hulu terdiri atas 15 jenis tanah yang didominasi oleh jenis tanah Asosiasi Andosol coklat dan Regosol coklat seluas 59.824 ha $(35,4 \%)$ kemudian Alluvial coklat kekelabuan, utamanya pada daerah utara sampai ke timur cekungan Bandung dan sebelah selatan cekungan Bandung. Tanah Alluvial merupakan tanah hasil endapan, erosi, dan luapan banjir, dengan aerasi dan drainase yang buruk. Tanah Andosol merupakan tanah yang berkembang dari bahan induk tuf dan abu vulkan intermedier, terutama terdapat di daerah berbukit dan bergunung dengan elevasi yang relatif tinggi (BPDAS, 2009), memiliki solum yang dalam, kaya bahan organik, drainase cepat, dan memiliki permeabilitas yang tinggi (Dharmawan dan Salim, 2016).

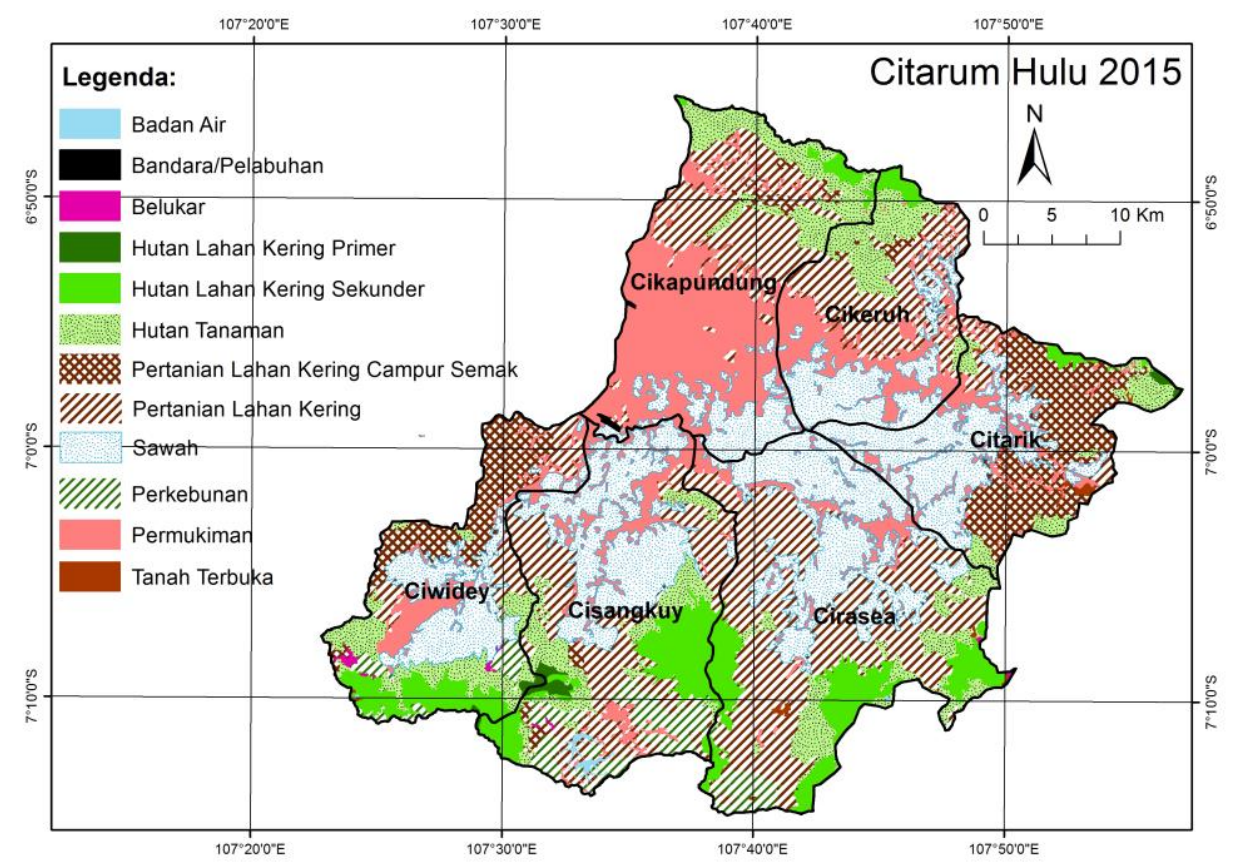

Gambar 3. Peta Penutupan Lahan DAS Citarum Hulu Tahun 2015

Berdasarkan hasil analisis peta tutupan lahan tahun 2015, DAS Citarum hulu didominasi oleh pertanian lahan kering sebesar 43.874,89 ha $(25,98 \%)$, dan sawah sebesar 40.059,16 ha (23,72\%). Sedangkan hutan sebesar 20,19\% $(34.095,25 \mathrm{ha})$ yang terdiri atas hutan lahan kering primer, hutan lahan kering sekunder, dan hutan tanaman (Dharmawan dan Salim, 2016). Peta tutupan lahan DAS Citarum hulu tahun 2015 ditunjukkan pada Gambar 3.

\subsection{Hasil Simulasi Model SWAT DAS Citarum Hulu}

Model SWAT yang digunakan untuk simulasi telah dikalibrasi dan divalidasi, dan hasil perhitungan koefisien Nash-Sutcliffe (ENS) antara debit bulanan observasi dan prediksi adalah 0,53 (memuaskan), dan nilai $\mathrm{R}^{2}=0,58$. Debit dugaan model dengan menggunakan data iklim dan peta tutupan lahan tahun 2015 ditunjukkan pada Gambar 4.

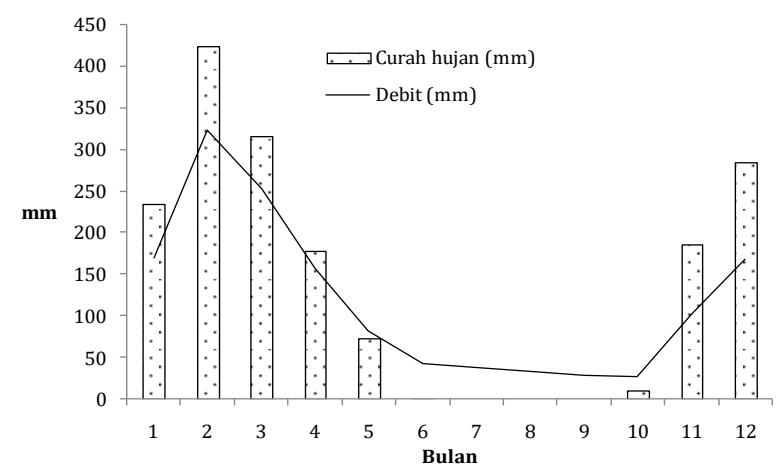

Gambar 4. Debit Hasil Dugaan Model SWAT pada Kondisi Existing 
Gambar 4 menunjukkan bahwa peningkatan curah hujan cenderung diikuti oleh peningkatan debit aliran. Beda waktu antara puncak curah hujan dan puncak hidrograf aliran DAS hulu terjadi hampir bersamaan atau tidak terlalu lama, ini menunjukkan bahwa curah hujan yang jatuh sebagian besar langsung menjadi air larian, dan air tidak memiliki kesempatan untuk terinfiltrasi ke dalam tanah. Setelah terjadi hujan yang cukup maka debit aliran sungai akan naik, dan akan turun kembali setelah hujan selesai. Jumlah dan variasi debit sungai tergantung pada tebal hujan, intensitas hujan, dan lama hujan serta distribusi dari curah hujan (Arsyad, 2010; Hadisusanto, 2010). Curah hujan yang langsung menjadi air larian dapat disebabkan oleh beberapa faktor diantaranya adalah kemiringan lereng, dan vegetasi penutup (tutupan lahan). Sebesar 43,59\% wilayah DAS Citarum hulu merupakan daerah berkemiringan sangat curam. Menurut Asdak (2014), semakin besar kemiringan lereng suatu DAS akan mempercepat laju air larian sehingga respon DAS terhadap curah hujan akan lebih cepat. Tutupan vegetasi maupun penggunaan lahan juga mempengaruhi besarnya air larian karena tiap-tiap jenis tutupan lahan akan memberikan respon yang berbeda terhadap curah hujan. Tutupan berupa hutan dengan tajuk, cabang/ranting, perakaran bahkan serasah dapat memperlambat laju aliran permukaan dan menahan air lebih lama di atas permukaan tanah sehingga dapat terinfiltrasi terlebih dahulu.

Hasil simulasi menunjukkan bahwa dari 1.710 mm total hujan yang jatuh sebanyak 48,61\% melimpas sebagai aliran permukaan; terinfiltrasi menjadi aliran dasar, aliran lateral, dan perkolasi masing-masing sebesar 30,29\%, 9,54\%, dan 21,65\%. Nilai Koefisien Rejim Aliran (KRA) atau biasa disebut Koefisien Rejim Sungai (KRS) DAS Citarum hulu adalah 31,4, termasuk kategori baik, karena rasio debit maksimum dan minimumnya masih dibawah angka 50 sesuai dengan Peraturan Menteri Kehutanan No. P.61/Menhut-II/2014 tentang Monev DAS. Alih fungsi lahan di DAS Citarum hulu sangat tinggi sehingga mempengaruhi fluktuasi debit dan dan dapat meningkatkan nilai KRS DAS. Akan tetapi, selain dipengaruhi oleh alih fungsi lahan, nilai KRS juga dipengaruhi oleh pola dan ragam curah hujan (Hidayat, et al. 2013). Curah hujan DAS Citarum hulu terutama wilayah selatan Bandung cukup tinggi dan hampir merata sepanjang tahun sehingga ikut mempengaruhi fluktuasi debit dan besaran nilai KRS.

\subsection{Hasil Skenario Tutupan Lahan Hutan DAS Citarum Hulu}

Rata-rata tahunan parameter hidrologi DAS Citarum hulu berdasarkan hasil analisis model pada beberapa skenario ditunjukan pada Tabel 2 .

Tabel 2. Parameter Hidrologi DAS Citarum Hulu Hasil Simulasi Model

\begin{tabular}{|c|c|c|c|c|c|}
\hline Simulasi & $\begin{array}{l}\text { Hasil Air } \\
(\mathrm{mm})\end{array}$ & $\begin{array}{c}\text { Aliran Permukaan } \\
(\mathrm{mm})\end{array}$ & $\begin{array}{c}\text { Aliran lateral } \\
(\mathrm{mm})\end{array}$ & $\begin{array}{c}\text { Perkolasi } \\
(\mathrm{mm})\end{array}$ & $\begin{array}{c}\text { Evapotranspirasi } \\
(\mathrm{mm})\end{array}$ \\
\hline 2015 (Existing) & 1637,46 & 933,03 & 174,93 & 513,33 & 383,50 \\
\hline Skenario 1 & 1634,58 & 1165,67 & 91,42 & 366,67 & 382,00 \\
\hline Skenario 2 & 1606,59 & 792,57 & 205,25 & 586,31 & 420,80 \\
\hline Skenario 3 & 1641,71 & 983,17 & 149,07 & 494,46 & 378,10 \\
\hline Skenario 4 & 1579,93 & 616,19 & 277,95 & 652,24 & 460,80 \\
\hline
\end{tabular}

Tabel 2 menunjukkan bahwa penurunan luas tutupan hutan dapat meningkatkan debit dan aliran permukaan. Sebaliknya jika terjadi peningkatan luas hutan akan meningkatkan infiltrasi tanah dan evapotranspirasi. Skenario 4 menunjukkan hasil hidrologi yang sangat baik, sedangkan yang terburuk adalah skenario 1 yaitu penurunan luas tutupan hutan sebesar $10 \%$ dari kondisis existing (2015). Adapun Skenario 2, yaitu peningkatan luas tutupan hutan sebesar 15\% mampu memperbaiki kondisi hidrologi DAS tetapi belum mencapai hasil yang baik, sehingga perlu diikuti dengan penerapan teknikteknik konservasi tanah dan air baik secara sipil teknis, vegetatif maupun kombinasi keduanya pada lahan-lahan pertanian.

Hasil air pada masing-masing skenario ditunjukkan pada Gambar 5.

Hasil air atau total aliran pada seluruh skenario tidak terlalu berbeda, kecuali pada Skenario 4 atau RTRWP. Hasil air pada skenario 4 sebesar 1.579,93 $\mathrm{mm}$, atau mampu menurunkan total aliran sebesar $3,5 \%$.

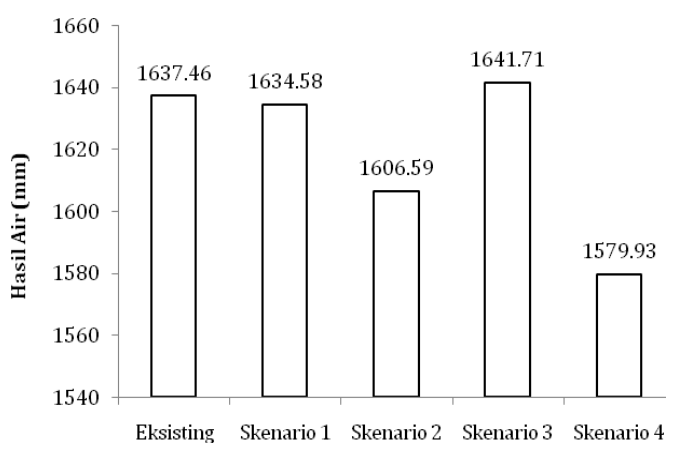

Gambar 5. Total Aliran Hasil Simulasi Model

Nilainya lebih kecil jika dibandingkan dengan skenario lain karena kondisi tutupan lahan yang sesuai dengan RTRWP memiliki luas kawasan hutan lebih dari $45 \%$ sehingga tingkat infiltrasinya juga tinggi, hal ini ditunjukkan oleh nilai aliran lateral dan perkolasi yang lebih tinggi. Adapun nilai evapotranspirasinya yang besar tidak akan mempengaruhi debit aliran sungai karena curah hujan di wilayah DAS Citarum hulu rata-rata lebih 
dari $1.500 \mathrm{~mm} /$ tahun. Menurut Hidayat et al. (2013), bahwa fluktuasi debit aliran Sungai Citarum antara lain juga disebabkan oleh pengelolaan lahan pertanian yang belum menerapkan teknik konservasi tanah dan air yang memadai dan penggunaan lahan yang tidak sesuai dengan kapasitas daya dukung lahan.

Peningkatan debit aliran sungai dapat terjadi akibat degradasi sifat fisik tanah karena alih fungsi hutan menjadi Areal Penggunaan Lain (APL). Semakin banyak area DAS terbangun, maka proses resapan air permukaan menjadi air tanah akan terganggu. Hal ini memicu peningkatan debit sungai pada musim hujan sehingga dapat menimbulkan banjir serta berdampak pada minimnya debit sungai di musim kemarau yang selanjutnya dapat menurunkan kualitas air sungai (Sulaeman, 2014; As-syakur et al., 2008).

Minimnya debit sungai di musim kemarau telah terjadi di beberapa wilayah di Jawa Barat, bahkan di beberapa wilayah hulu mengalami periode defisit air di waktu-waktu tertentu. Salah satunya adalah Sub DAS Citarik yang mempunyai periode defisit air yang paling panjang, yaitu selama 11 bulan dan bulan surplus hanya terjadi pada bulan Desember (BPDAS Citarum-Ciliwung dan IPB, 2011). Aliran permukaan dan koefisien aliran permukaan pada masing-masing skenario ditunjukkan pada Gambar 6.

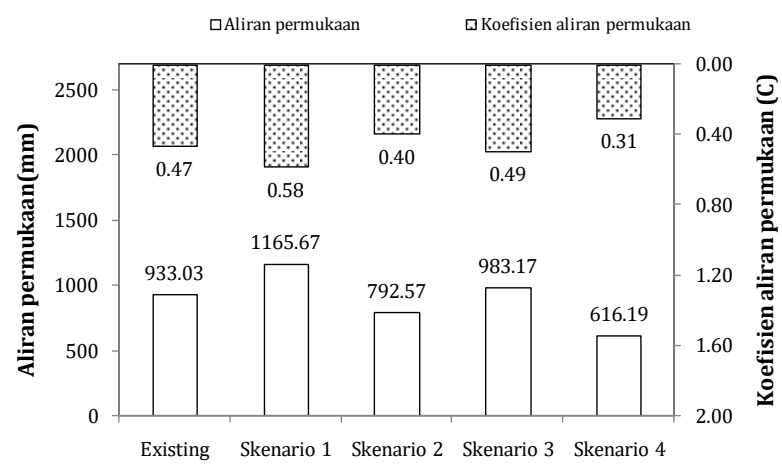

Gambar 6. Aliran Permukaan dan Koefisien Aliran Permukaan Hasil Simulasi Model

Pada Skenario 1 disimulasikan hutan seluas $10 \%$ dikonversi menjadi area permukiman menyebabkan terjadinya peningkatan aliran permukaan sebesar $24,9 \%$ dari kondisi existing. Penurunan tutupan hutan tersebut menyebabkan $58 \%$ air hujan yang jatuh melimpas sehingga dapat memicu terjadinya banjir terutama pada saat intensitas hujannya tinggi. Alih fungsi lahan mengakibatkan perubahan limpasan permukaan (overlandflow), total limpasan, dan fluktuasi aliran sungai. Kondisi limpasan permukaan suatu wilayah bergantung pada karakteristik hujan dan kondisi biofisik permukaan lahan (Setyowati, 2010; Anna, 2014).

Koefsien aliran permukaan (C) adalah perbandingan antara besarnya air hujan yang melimpas dengan jumlah curah hujan yang jatuh.
Skenario 4 memiliki nilai C sedang, sedangkan skenario lain tinggi bahkan pada skenario 1 sangat tinggi. Penurunan luas hutan karena dikonversi menjadi pertanian lahan kering dan permukiman menyebabkan berkurangnya wilayah resapan air sehingga terjadi penurunan kapasitas penyimpanan air (water retention). Kondisi ini dapat menyebabkan peningkatan erosi dan banjir terutama di wilayah hulu DAS.

Pengaruh perubahan tutupan lahan terhadap erosi ditunjukkan pada Gambar 7.

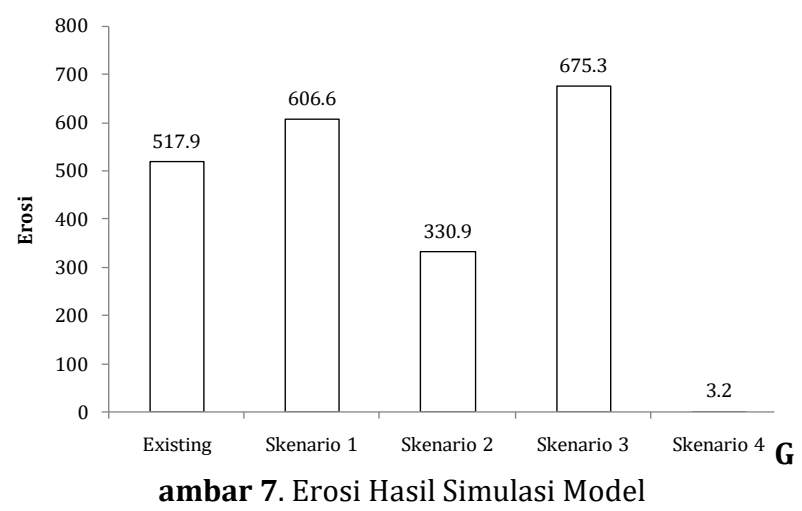

Gambar 7 menunjukkan bahwa rata-rata erosi pada kondisi existing adalah 517,9 ton/ha/thn. Tingginya erosi di wilayah hulu DAS sering terjadi hampir di seluruh wilayah DAS. Daerah Citarum hulu umumnya adalah wilayah berkemiringan lereng curam dengan curah hujan yang cukup tinggi sehingga sangat mendukung pengembangan tanaman hortikultura. Kondisi ini memicu meluasnya konversi lahan hutan maupun perkebunan menjadi area pertanian lahan kering. Intensitas kegiatan pertanian yang tinggi pada lahan berkemiringan lereng cukup terjal dengan kondisi tanpa vegetasi (sangat terbuka) merupakan sumber terjadinya erosi tingkat berat (Haryanto, 2013), dan hal ini sangat mempengaruhi kondisi DAS Citarum baik debit, aliran permukaan dan tingkat erosinya.

Erosi pada skenario 2 mengalami penurunan sebesar 187 ton/ha/tahun atau 36,12\% dari kondisi existing. Akan tetapi, angka ini masih termasuk tinggi sehingga masih belum efektif dalam menurunkan laju erosi lahan. Kondisi DAS Citarum hulu yang didominasi oleh wilayah yang berkemiringan lereng curam sangat mudah mengalami erosi terutama pada lahan-lahan pertanian. Peningkatan luas tutupan hutan hingga mencapai lebih dari $45 \%$ tidak mudah untuk dilakukan karena permasalahan konversi lahan melibatkan banyak pihak terkait baik masyarakat, pemerintah, dan pihak swasta.

Erosi yang terjadi pada skenario 3 mencapai 675,3 ton/ha/tahun, paling tinggi jika dibandingkan dengan skenario lainnya. Konversi lahan hutan sebesar $10 \%$ menjadi pertanian lahan kering menyebabkan terjadinya peningkatan erosi rata-rata sebesar $30,4 \%$ atau 157,4 ton/ha/tahun. Hasil penelitian Anwar et al., (2013) menunjukkan bahwa penurunan luas tutupan hutan dan kebun karet serta 
peningkatan lahan terbuka di DAS Barito Hulu menyebabkan peningkatan erosi rata-rata sebesar 12,63 ton/ha.

Skenario 4 merupakan implementasi RTRW Provinsi Jawa Barat, dimana terdapat kawasan budidaya enclave 25,71\%, perkotaan $28,27 \%$ dan sisanya merupakan kawasan lindung sebesar 50,59\%. Skenario 4 mampu menekan erosi sebesar 99,39\% dari kondisi existing. Hal ini disebabkan oleh pola ruang berdasarkan RTRW ini tidak mengakomodir pertanian lahan kering seperti pada kondisi existing yang merupakan salah satu penyebab tingginya erosi pada wilayah hulu DAS.

Hasil simulasi beberapa skenario menunjukkan bahwa tutupan lahan yang didominasi oleh hutan akan memberikan dampak yang lebih baik terhadap parameter hidrologi suatu DAS. Penurunan luas tutupan hutan seperti yang diuji dengan skenario 1 menunjukkan adanya peningkatan debit aliran, aliran permukaan dan erosi, meskipun kecenderungan keduanya cukup berbeda. Peningkatan luas tutupan permukiman akan meningkatkan besarnya aliran permukaan, sedangkan peningkatan luas lahan pertanian akan meningkatkan besarnya tingkat erosi lahan.

Skenario 4 merupakan aplikasi pola ruang RTRW Provinsi Jawa Barat, dan menghasilkan parameter hidrologi (debit, aliran permukaan dan erosi) yang lebih baik jika dibandingkan skenario lainnya. Pola ruang RTRWP menunjukkan luasan untuk kawasan perlindungan adalah 50,95 \% terdiri atas kawasan konservasi, hutan lindung, kawasan non hutan yang sesuai untuk hutan lindung, hutan produksi, dan kawasan non hutan untuk resapan air.

Skenario 4 mampu menekan laju aliran permukaan yang terjadi mencapai 33,96\% dari kondisi existing. Akan tetapi, keadaan tutupan lahan saat ini sangat tidak sesuai dengan RTRWP yang ada menyebabkan perlu banyak penyesuaian, diantaranya adalah luas sawah yang saat ini mencapai 24,35\%, di RTRWP hanya seluas 0,74\%; luas tutupan hutan saat ini sebesar 19,32\% berubah menjadi kawasan lindung (50,59\%) yang terdiri atas kawasan hutan dan non hutan yang diperuntukkan untuk hutan konservasi, hutan lindung, kawasan non hutan untuk hutan lindung, resapan air dan kawasan budidaya hutan produksi, serta perubahan tutupan lahan lainnya. Kondisi ideal ini membutuhkan waktu dan biaya yang tidak sedikit dalam mewujudkannya, disamping dibutuhkan sikap konsisten para pihak terkait dalam melaksanakan kegiatan pembangunan agar mengacu pada RTRWP yang telah dibuat.

Rencana Tata Ruang Wilayah Provinsi (RTRWP) Jawa Barat tetap dapat dijadikan acuan pembangunan wilayah DAS Citarum untuk jangka panjang, tetapi untuk jangka pendek skenario 2 dapat dijadikan alternatif target yang harus dicapai dalam jangka waktu tertentu. Proses ini dapat dilakukan secara bertahap dengan menyiapkan alternatif lahan pengganti melalui mekanisme yang terlebih dahulu dikaji dengan mempertimbangkan aspek sosial dan ekonomi masyarakat.

\section{Kesimpulan}

Penurunan luas tutupan hutan dapat meningkatkan debit dan aliran permukaan, sebaliknya peningkatan luas hutan akan meningkatkan infiltrasi dan evapotranspirasi.

Hutan yang dikonversi menjadi permukiman akan meningkatkan limpasan permukaan dan yang dikonversi menjadi pertanian lahan kering akan meningkatkan besarnya erosi.

Implementasi Skenario 4 yaitu RTRW Provinsi Jawa Barat akan memperbaiki kondisi hidrologi DAS Citarum Hulu. Akan tetapi, banyaknya ketidaksesuaian kondisi existing dengan RTRWP yang dibuat akan membutuhkan waktu yang cukup lama dan biaya yang besar, sehingga alternatif jangka pendek yang bisa dilakukan adalah dengan Skenario 2 berupa konversi pertanian lahan kering menjadi hutan sehingga total hutan minimal adalah $45 \%$ dari tutupan lahan wilayah hulu sehingga dapat memperbaiki kondisi hidrologi DAS meskipun belum optimal.

\section{DAFTAR PUSTAKA}

Anna, A. N. 2014. Analisis Potensi Limpasan Permukaan (Run Off) Menggunakan Model Cook'S Di DAS Penyangga Kota Surakarta untuk Pencegahan Banjir Luapan Sungai Bengawan Solo. Prosiding Seminar Nasional Pembangunan Berkelanjutan di DAS Bengawan Solo. p. 3019325.

Anwar, M., H. Pawitan, K. Murtilaksono, dan I. N. S. Jaya. 2011. Respons Hidrologi Akibat Deforestasi di DAS Barito Hulu, Kalimantan Tengah . Jurnal Manajemen Hutan Tropika, Vol. XVII (3): 119126.

Asdak, C. Hidrologi dan Pengelolaan Daerah Aliran Sungai. Gadjah Mada University Press. Yogyakarta.

Arsyad, S. 2010. Konservasi Tanah dan Air. IPB Press. Bogor.

As-syakur, A.R., I.W. Suarna, I.W. Adnyana, I.W. Rusna, I.A.A. Laksmiati, dan I.W. Diara. 2008. Studi Perubahan Penggunaan Lahan di DAS Badung. Jurnal Bumi Lestari Vol. 10 (1): 200208.

Badan Litbang dan Inovasi. 2016. Karakteristik DAS Dan Jenis Hutan Berpengaruh Pada Luas Hutan Optimal Dalam DAS. Badan Litbang dan Inovasi, Kementerian Kehutanan. http://www.fordamof.org/berita/post/2511\#. Diakses 29 Februari 2016.

BPDAS CItarum Ciliwung. 2009. Rencana Pengelolaan DAS Citarum Terpadu, Buku I: Laporan Utama. BPDAS Citarum-Ciliwung. Bogor.

BPDAS Citarum-Ciliwung dan IPB. 2011. Penyusunan Rencana Tindak Pengelolaan Das Citarum. Laporan Utama. Kerjasama BPDAS CitarumCiliwung dengan Fakultas Kehtanan IPB. Bogor. 
Dharmawan, I.W. dan A.G. Salim. 2016. Analisis Fluktuasi Curah Hujan dan Debit Aliran DAS Citarum Bagian Hulu, dalam Mulyanto, B. dan Dharmawan, I.W., (ed), Bunga Rampai Pengelolaan Lahan dan Air Berkelanjutan dengan Melibatkan Masyarakat. Forda Press. Bogor. p.21-33.

Hadisusanto, N. 2010. Aplikasi Hidrologi. Jogja Media Utama. Yogyakarta.

Hanifiyani, M.M. 2915. Analisis Hidrologi Menggunakan Model SWAT di Sub DAS Cilebak Kabupate Bandung. Skripsi. Fkultas Kehutanan Institut Pertanian Bogor.

Haryanto, E.T. 2013. Erosi dan Sedimentasi di Daerah Aliran Sungai (DAS) Citarum Hulu dan Umur Operasional PLTA Saguling. Bulletin of Scientific Contribution, Vol. 11 (2): 74-88.

Hidayat, Y., K. Murtilaksono, E.D. Wahjunie, dan D.R. Panuju. 2013. Pencirian Debit Aliran Sungai Citarum Hulu. Jurnal Ilmu Pertanian Indonesia. Vol. 18 (2):109-114.

Imansyah, M.F. 2012. Studi Umum Permasalahan dan Solusi DAS Citarum serta Analisis Kebijakan Pemerintah. Jurnal Sosioteknologi Ed. 25 (11):17-31.

Irsyad, F. 2011. Analisis Debit Sungai Cidanau dengan Aplikasi SWAT. Tesis. Sekolah Pascasarjana Institut Pertanian Bogor.

Kementerian Kehutanan dan UGM. 2014. Penyusunan Klasifikasi DAS Wilayah BPDAS Citarum-Ciliwung. Buku I: Laporan Akhir. Kerjasama BPDAS Citarum-Ciliwung dengan Puspic UGM. Bogor.

Kementerian Lingkungan Hidup dan Kehutanan. 2015. Peta Penutupan Lahan. Direktorat Inventarisasi dan Pemantauan Sumber Daya Hutan, Dirjen Planologi. www.webgis.dephut.go.id. Diakses 1 Agustus 2015.

Maulani, N., Sunardi, D. Sumiarsa, dan Djuwansah. 2013. Identifikasi Kemiskinan Air di Daerah Aliran Sungai Citarum Hulu: Kasus Daerah Bandung Raya. Jurnal Ilmu Lingkungan Vol. 11(2): 92-99.
Moriasi, D.N., Arnold, J.G., Van Liew, M.W., Bingner, R.L., Harmel, R.D., Veith, T.L. 2007. Model Evaluation Guidelines For Systematic Quantification of Accuracy in Watershed Simulations. Transactions of the ASABE. 50 (3):885-900.

Mubarok, Z., K. Murtilaksono, dan E.D. Wahjunie. 2015. Kajian Respons Perubahan Penggunaan Lahan terhadap Karakteristik Hidrologi DAS Way Betung-Lampung. Jurnal Penelitian Kehutanan Wallacea Vol. 4 (1):1-10.

Mulyana, N. 2012. Analisis Luas Tutupan Hutan terhadap Ketersediaan Green Water dan Blue Water di Sub DAS Gumbasa dan Sub DAS Cisadane Hulu dengan Aplikasi Model SWAT. Disertasi. Sekolah Pascasarjana Institut Pertanian Bogor. Neitsch, S.L., J.G. Arnold, J.R. Kiniry, and J.R. Williams. 2011. Soil and Water Assesment, Theoritical Documentation Version 2009. Grassland, Soil and Water Research Laboratory-Agricultural Research Service-Black Land Research Center-Texas Agrilife Research. Texas.

Republik Indonesia. Menteri Kehutanan Republik Indonesia. 2014. Lampiran Monitoring dan Evaluasi Pengelolaan Daerah Aliran Sungai. Jakarta. (Nomor: P. 61 /Menhut-II/2014)

Sulaeman, D. 2014. Kajian Dampak Perubahan Penggunaan Lahan Terhadap Debit Aliran DAS Ciujung. INFRASTRUKTUR Vol. 4 (2): 78 - 85.

Setyowati, D., L. 2010. Hubungan Hujan dan Limpasan pada Sub DAS Kecil Penggunaan Lahan Hutan, Sawah, Kebun Campuran di DAS Kreo, Jurnal Forum Geografi, volume 14 (1):39-56.

Yustika, R. D. 2013. Pengelolaan Lahan Terbaik Hasil Simulasi Model SWAT untuk Mengurangi Aliran Permukaan di Sub DAS Ciliwung Hulu. Tesis. Sekolah Pascasarjana Institut Pertanian Bogor.

Yusuf, S.M. 2010. Kajian Respon Perubahan Penggunaan Lahan terhadap Karakteristik Hidrologi pada DAS Cirasea Menggunakan Model MSWAT. Tesis. Sekolah Pascasarjana Institut Pertanian Bogor. 